\title{
PEMETAAN PEMERATAAN PENDIDIKAN MENGGUNAKAN SELF ORGANIZING MAPS (SOM) TERINTEGRASI SISTEM INFORMASI GEOGRAFIS
}

\author{
Syarli $^{1}$, Akhmad Qashlim ${ }^{2}$ \\ Program Studi Teknik Informatika ${ }^{1}$ \\ Program Studi Sistem Informarsi ${ }^{2}$ \\ Universitas Al Asyariah Mandar
}

Jalan Budi Utomo No. 2 Madatte, Kab. Polewali Mandar, Prov. Sulawesi Barat

\begin{abstract}
ABSTRAK
Pemetaan Pendidikan disuatu Daerah dilakukan untuk mengetahui tingkat kondisi pendidikan pada suatu wilayah. Informasi yang dihasilkan dapat membantu pemerintah dalam menentukan wilayah prioritas pembangunan. Pemetaan kondisi pendidikan dilakukan menggunakan metode Self Organizing Maps (SOM) dengan sembilan indikator pemerataan pendidikan. Pada pengelolaan data preprocessing menggunakan metode Min-Max Normalization untuk menjaga agar range antara variable satu dengan yang lain berada pada range 0-1. Hasil pemetaan SOM dengan menggunakan data latih tahun 2010 - 2013 sebanyak 64 Data dan data uji tahun 2014 sebanyak 16 data menghasilkan akurasi $81,25 \%$. Keakuratan hasil sangat bergantung pada model data latih, jumlah data latih dan jumlah iterasi. Tingkat akurasi yang dihasilkan setelah dilakukan perbandingan dengan data aktual, menunjukkan bahwa SOM dapat digunakan sebagai metode untuk melakukan pemetaan.
\end{abstract}

Kata Kunci : SOM, Min-Max Normalization, Pemerataan Pendidikan.

\begin{abstract}
Mapping in a District Education conducted to determine the condition of education in the region. The resulting information can assist the government in determining the development priorities. Mapping of the situation of education conducted using Self Organizing Maps (SOM) with nine indicators of educational equity. On the management of data preprocessing using the Min-Max Normalization to keep the range of variables to one another is in the range 0-1. SOM mapping results using training data years 2010 - 2013 a total of 64 data and test data in 2014 a total of 16 data resulted in $81.25 \%$ accuracy. Accuracy of results is highly dependent on the model training data, the training data and the number of iterations. The level of precision resulting from the comparison with real data, indicates that SOM can be used as a method for mapping.
\end{abstract}

Keywords : SOM, Min-Max Normalization, Educational Equity 


\section{Pendahuluan}

Klasifikasi adalah proses mencari model atau fungsi yang menerangkan dan membedakan kelas data, dengan tujuan dapat menggunakan model untuk meramalkan kelas objek dari kelas label yang tidak diketahui. Klasifikasi yang dihasilkan harus maksimal membedakan setiap kelas dengan kelas yang lain, dan menyajikan gambaran terorganisir dari kumpulan data. Tujuan dari klasifikasi memudahkan untuk mengetahui model, karakter dan konsep dari data set berdasarkan kelas sehingga membantu dalam penentuan keputusan [3].

Penelitian untuk klasifikasi pada berbagai bidang telah banyak dilakukan dengan berbagai macam metode. Peneltian dengan metode bayesian pada berbagai bidang untuk klasifikasi telah dilakukan [20]; [22], [7]. Klasifikasi pola adalah salah satu daerah yang paling penting pada kecerdasan buatan dan dalam tahun-tahun belakangan ini, jaringan saraf tiruan telah menjadi alat bantu yang baik untuk klasifikasi pola karena fitur - fitur dengan kemampuan yang luar biasa, seperti model sistem non linier, pembelajaran sendiri, dan penyusuaian diri [26]. Peneltian menggunakan neural network juga telah banyak dilakukan pada berbagai bidang [27].

Berdasarkan uraian diatas, maka metode yang akan digunakan pada penelitian ini adalah model jaringan syaraf tiruan (JST). Self Organizing Maps (SOM) merupakan salah satu metode JST [9]. Penelitian menganalisis fitur geomorphometric menggunakan dua metode Wood morfometrik parameterisasi dan SOM. Hasil penelitian menunjukkan bahwa SOM lebih baik dibandingkan dengan wood morfometrik untuk pengelompokkan [2]. Penelitian untuk Klasifikasi dengan menggunakan K-Means dan SOM, hasil penelitian merekomendasikan penggunaan SOM untuk pengklasifikasian [13]. Penelitian pendekatan multivariate menggunakan SOM dan hasil menunjukkan bahwa SOM adalah alat bantu yang baik dalam interpretasi dataset kompoleks [12]. Penelitian Pemetaan pola menggunakan SOM, hasil penelitian menunjukkan bahwa SOM baik untuk pemetaan data multivariate [14].

Penelitian ini akan menggunakan metode SOM dalam menganalisis kasus yang akan dilteliti. SOM digunakan untuk melakukan pemetaan pendidikan dengan menggunakan parameter pemerataan pendidikan. Walaupun penelitian pemetaan pendidikan pernah dilakukan [24], namun perbedaan penelitian yang akan di lakukan dengan penelitian sebelumnya terletak pada parameter yang digunakan dan juga pada hasil pemetaan. Penelitian ini menggunakan 5 (lima) parameter dan hasil ini disajikan dalam bentuk peta serta warna yang ditampilkan pada peta menunjukkan kelas atau kondisi pendidikan pada suatu wilayah.

\section{Kerangka Teori}

\subsection{Jaringan Saraf Tiruan (JST)}

Jaringan saraf tiruan merupakan suatu konsep rekayasa pengetahuan dalam bidang kecerdasan buatan yang didesain dengan mengadopsi sistem saraf manusia, yang pemprosesan utamanya ada pada otak dan bagian terkecil pada otak adalah sel saraf yang disebut pemroses informasi atau neuron [18].
Pada JST terdapat dua proses pembelajaran yaitu :

1. Pembelajaran terawasi (Supervised learning), Metode pembelajaran jaringan saraf disebut terawasi jika output yang diharapkan telah diketahui sebelumnya. Pada proses pembelajaran, satu pola input akan diberikan ke satu neuron pada lapisan input. Pola ini akan dirambatkan disepanjang jaringan saraf hingga sampai ke neuron pada lapisan output. Lapisan output ini akan membangkitkan pola output yang nantinya akan dicocokkan dengan pola output targetnya. Apabila terjadi perbedaan antara output hasil pembelajaran dengan pola target, maka disini akan muncul error. Apabila error ini masih cukup besar, mengindikasikan bahwa masih perlu dilakukan lebih banyak pembelajaran lagi. Ada beberapa metode pembelajaran terawasi yang telah diciptakan oleh para peneliti, diantaranya yang sering diaplikasikan adalah single perceptron, multi perceptron, dan backpropagation.

2. Pembelajaran tak terawasi (Unsupervised learning), Pada metode pembelajaran yang tak terawasi ini, tidak memerlukan target output. Pada metode ini, tidak dapat ditentukan hasil seperti apakah yang diharapkan selama proses pembelajaran. Selama proses pembelajaran, nilai bobot disusun dalam suatu range tertentu tergantung pada nilai input yang diberikan. Tujuan pembelajaran ini adalah mengelompokkan unit-unit yang hampir sama dalam suatu area tertentu. Pembelajaran ini biasanya sangat cocok untuk pengelompokan (klasifikasi) pola.Ada beberapa metode pembelajaran tak terawasi yang telah diciptakan oleh para peneliti, diantaranya yang sering diaplikasikan adalah self organizing maps (SOM), dan Hopfield.

\subsection{Self Organizing Maps (SOM)}

SOM adalah tehnik yang cocok untuk menganalisis, model dan mengendalikan berbagai jenis proses dan system [6]. Secara umum, algoritma SOM mengkluster sampel atau pola kedalam kelas yang telah ditetapkan (jumlah neuron yang dipilih oleh pembuat model) dan juga memerintahkan kelas kedalam peta yang bermakna (kelestarian topologi atau property yang dinginkan). Struktur khas dari SOM terdiri dari dua lapisan : lapisan masukan dan kohonen atau lapisan output. Lapisan masukan berisi satu neuron untuk setiap variabel dalam kumpulan data. Lapisan neuron kohonen yang terhubung ke setiap neuron dilapisan masukan sampai bobot yang menyesuaikan diri atau parameter jaringan. Bobot vector pada lapisan kohonen memberikan representasi dari distribusi vector input dalam model yang diinginkan

SOM dibentuk menjadi JST layer tunggal dengan jumlah neuron pemroses yang sama dengan K kelompok. Setiap data masukan mempunyai hubungan (dan bobot) pada setiap neuron. Komputasi sinyal keluaran tidak 
menggunakan inner-product seperti pada perceptron, tetapi menggunakan Euclidean kuadrat antara data masukan dengan bobot pada setiap neuron pemroses. Akumulasi sinyal yang didapat tidak perlu diaktivasi ( fungsi aktivasi linear) karena fungsi aktivasi tidak berpengaruh pada pemilihan neuron pemenang yang akan memperbarui bobotnya dan bobot tetangganya[16]

Prosedur yang harus dilakukan pada penerapan SOM terbagi dalam tiga kategori, sebagai berikut :

1. Pengumpulan dan normalisasi data : yang terpenting pada bagian normalisasi adalah untuk mencegah dampak dari variabel yang memiliki nilai lebih tinggi dibandingkan dengan variabel lainnya. Konsekuensi berkala, normalisasi, dengan mengubah semua variabel ke kisaran misalnya $0-1$, memastikan bahwa semua variabel memiliki kepentingan yang sama dalam pembentukan SOM;

2. Pelatihan : setelah persiapan dan normalisasi data, sebuah vector input dari data matriks yang dimasukkan ke prosedur pelatihan iteratif untuk membentuk SOM;

3. Mengekstrak informasi dari Pelatihan SOM : sesudah pelatihan SOM, pasca diproses menghasilkan peta yang dinginkan berdasar visualisasi, kluster atau pemodelan local tujuan.

suatu lapisan yang berisi neuron-neuron akan menyusun dirinya sendiri berdasarkan masukan nilai tertentu dalam suatu kelompok. Selama proses penyusunan diri, kelompok yang memiliki vector bobot paling cocok dengan pola masukan akan terpilih sebagai pemenang. Neuron yang menjadi pemenang beserta dengan neuronneuron tetangganya akan memperbaiki bobot - bobotnya, apabila ingin dibagi data-data menjadi $\mathrm{K}$ cluster maka lapisan kompetitif akan terdiri atas $\mathrm{K}$ buah neuron. Algoritma SOM seperti dibawah ini, misalkan himpunan dari $\mathrm{M}$ nilai-nilai field untuk record $\mathrm{ke}-\mathrm{n}$ menjadi sebuah vector masukan $X_{n}=X_{n 1}, X_{n 2}, X_{n 3, \ldots}, X_{n m}$, dan himpunan dari $\mathrm{m}$ bobot untuk sinyal keluaran tertentu $\mathrm{j}$ menjadi vector

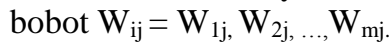

Proses pembelajaran akan berlangsung terus menerus sehingga epoch mencapai maksimum epoch. Adapun urutan algoritmanya sebagai berikut [13] :

1. Inisialisasi bobot $\mathrm{W}_{\mathrm{ij}}$. Set parameter-parameter tetangga dan set parameter learning rate;

2. Selama jumlah maksimal iterasi belum tercapai, maka lakukan langkah :

a. Untuk masing - masing vector input $\mathrm{x}$, lakukan :

b. Untuk masing - masing $\mathrm{j}$, lakukan perhitungan :

$$
D(j)=\sum_{i}\left(w_{i j-} x_{i}^{2}\right)
$$

c. Cari indeks dari sejumlah neuron, yaitu $\mathrm{D}_{\mathrm{ij}}$ yang mempunyai nilai terkecil.

d. Untuk neuron $\mathrm{j}$ dan semua neuron yang menjadi tetangga $\mathrm{J}$ dalam radius $\mathrm{R}$ dilakukan pembaruan bobot :

$$
W_{i j}(\text { baru })=W_{i j}(\text { lama })+\eta\left[X_{i-} W_{i j}(\text { lama })\right]
$$

e. Perbarui learning rate.

\subsection{Sistem Informasi Geografi (SIG)}

SIG adalah suatu sistem berbasis komputer untuk menangkap, menyimpan, mengecek, mengintegrasikan, memanipulasi, dan menampilkan data dengan peta digital [20].

\subsection{Pemerataan Pendidikan}

Dalam pembukaan Undang-Undang Dasar (UUD) Negara Republik Indonesia Tahun 1945 dinyatakan bahwa salah satu tujuan Negara Republik Indonesia adalah mencerdaskan kehidupan bangsa dan untuk itu setiap warga negara Indonesia berhak memperoleh pendidikan yang bermutu sesuai dengan minat dan bakat yang dimilikinya tanpa memandang status sosial, ras, etnis, agama, dan gender. Pemerataan dan mutu pendidikan akan membuat warga negara Indonesia memiliki keterampilan hidup (life skills) sehingga memiliki kemampuan untuk mengenal dan mengatasi masalah diri dan lingkungannya, mendorong tegaknya masyarakat madani dan modern yang dijiwai nilai-nilai Pancasila.

Pemerataan pendidikan adalah setiap warga Negara mendapatkan kesempatan yang sama dalam pendidikan. Adapun indikator pemerataan pendidikan sebagai berikut : Angka Partisipasi Kasar (APK), Angka Partisipasi Murni (APM), Perbandingan Antar Jenjang Pendidikan (PAJ), Rasio Siswa per Guru (R-S/G), Angka Melanjutkan (AM).

\subsection{Normalization}

Normalization atau normalisasi adalah proses transformasi dimana sebuah atribut numerik diskalakan dalam range yang lebih kecil seperti -1,0 sampai 1,0, atau 0,0 sampai 1,0. Ada Beberapa metode atau tehnik yang diterapkan untuk normalisasi data yaitu sebagai berikut : Min-max Normalization, Z-Score Normalization, Normalization by Decimal Scalling.

\subsubsection{Min - Max Normalization}

Min - Max Nomalization memetakan sebuah value $v$ dari atribut $A$ menjadi $v^{l}$ ke dalam range [new_min ${ }_{A}$, new_max $]$ ] berdasarkan rumus :

$v^{1}=\frac{v-\min _{A}}{\max _{A}-\min _{A}+n e w_{-} \min _{A}}\left(n e w_{-} \max _{A}-n e w_{-} \min _{A}\right)$

$\begin{array}{ll}\text { Dengan : } & \\ V & \text { I: Nilai Hasil Normalisasi ; } \\ V & \text { :Nilai Data yang akan di Normalisasi } ; \\ \text { min }_{A} & \text { :Nilai Minimum Data ; } \\ \text { max }_{A} & \text { :Nilai Maksimum Data ; } \\ \text { new_min } & \text { :Nilai Minimum yang di Inginkan ; } \\ \text { new_max } & \text { :Nilai Maksimum yang diinginkan. }\end{array}$

3. Metodologi

\subsection{Prosedur Penelitian}

Prosedur penelitian pemetaan pemerataan pendidikan menggunakan SOM digambarkan dalam bentuk bagan seperti pada gambar 3.1 


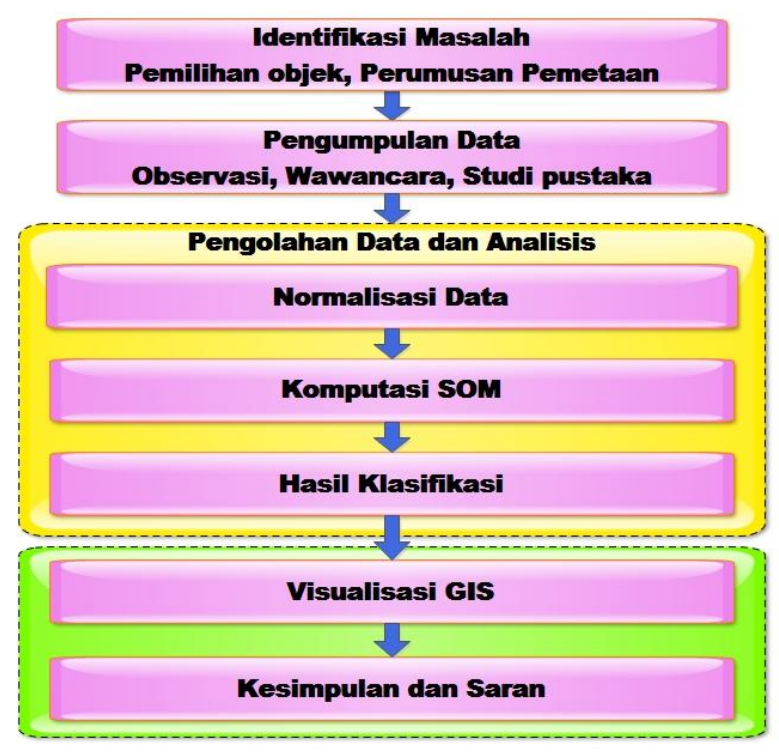

Gambar 3.1. Prosedur Penelitian

\subsection{Kerangka Sistem}

Sistem informasi pemetaan pendidikan yang dirancang dapat menyajikan informasi berupa klasifikasi tingkat pendidikan disuatu wilayah sehingga dapat dimanfaatkan oleh Pemerintah Kabupaten Polewali Mandar dalam penentuan prioritas pembangunan dibidang pendidikan.

Berikut adalah kerangka sistem informasi pemetaan pendidikan yang terdiri dari input, proses dan output seperti yang terlihat pada gambar 3.2 berikut :

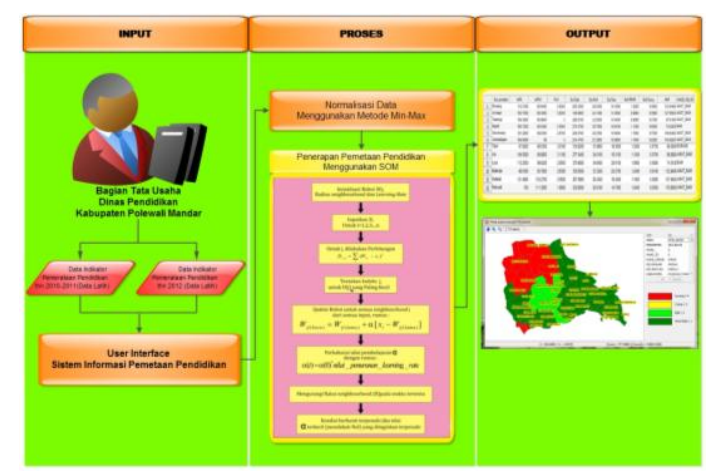

Gambar 3.2. Kerangka Sistem

Berdasarkan gambar kerangka sistem diatas dapat dijelaskan bahwa alur dari sistem tersebut dimulai dengan input data indikator pemerataan pendidikan yang dilakukan oleh bagian tata usaha dari dinas pendidikan kabupaten Polewali Mandar dan selanjutnya pada tahapan proses akan dilakukan normalisasi data input agar nilai dari setiap indikator berada dalam kisaran 0 - 1 . Setelah proses normalisasi selesai maka dilanjutkan dengan komputasi SOM, pada proses komputasi SOM langkah pertama yang dilakukan adalah melakukan pelatihan terhadap data latih yang telah memiliki kelas sebagai pembelajaran, setelah proses pelatihan selesai maka dilanjutkan dengan melakukan proses pengujian pada data uji yang tidak memiliki kelas. Hasil dari pengujian tersebut berupa data uji yang telah memiliki kelas dan selanjutnya hasil dari data pengujian diintegrasikan kedalam sistem informasi geografi dalam bentuk peta wilayah, dalam hal ini tingkat kondisi pendidikan dibedakan berdasarkan warna sesuai dengan kelas masing-masing.

\section{Hasil dan pembahasan \\ 4.1 Hasil Penelitian}

Hasil dari penelitian ini adalah sebuah sistem informasi pemetaan pendidikan yang menghasilkan sebuah laporan berupa klasifikasi tingkat pendidikan berdasarkan wilayah kecamatan dan penyajian informasinya dalam bentuk peta. Hasil dari laporan tersebut dapat pula dijadikan sebagai rujukan bagi pemerintah dalam menetukan prioritas pembangunan dibidang pendidikan.

\subsection{Pembahasan}

Data yang digunakan pada penelitian ini adalah data indikator pemerataan pendidikan tahun 2010 - 2013 sebagai data latih dan data indikator pemerataan pendidikan tahun 2014 sebagai data uji yang diperoleh dari Dinas Pendidikan Kabupaten Polewali Mandar, dalam hal ini terdapat 16 wilayah kecamatan.

\subsubsection{Normalisasi Data}

Pada tahapan ini dilakukan normalisasi data latih dan data uji. Hasil normalisasi latih data dapat dilihat pada tabel 4.1 dan normlisasi data uji dapat dilihat pada tabel 4.2 berikut :

Tabel 4.1. Hasil Normalisasi Data Latih

\begin{tabular}{|c|c|c|c|c|c|c|}
\hline V & X1 & X2 & X3 & X4 & X5 & Kelas \\
\hline V1 & 0.58 & 0.48 & 0.31 & 0.38 & 0.70 & Amat Baik \\
\hline V2 & 0.41 & 0.34 & 0.37 & 0.40 & 0.54 & Amat Baik \\
\hline V3 & 0.25 & 0.21 & 0.54 & 0.33 & 0.56 & Baik \\
\hline V4 & 0.43 & 0.37 & 0.41 & 0.38 & 0.61 & Amat Baik \\
\hline V5 & 0.65 & 0.49 & 0.47 & 0.28 & 0.48 & Amat Baik \\
\hline V6 & 0.43 & 0.35 & 0.33 & 0.40 & 0.54 & Amat Baik \\
\hline V7 & 0.39 & 0.33 & 0.47 & 0.40 & 0.51 & Cukup \\
\hline V8 & 0.21 & 0.20 & 0.30 & 0.40 & 0.19 & Kurang \\
\hline V9 & 0.32 & 0.26 & 0.22 & 0.23 & 0.40 & Baik \\
\hline V10 & 0.27 & 0.23 & 0.21 & 0.20 & 0.54 & Cukup \\
\hline V11 & 0.69 & 0.65 & 0.58 & 0.20 & 0.35 & Baik \\
\hline V12 & 0.74 & 0.66 & 0.28 & 0.25 & 0.35 & Amat Baik \\
\hline V13 & 0.13 & 0.10 & 0.28 & 0.40 & 0.41 & Cukup \\
\hline V14 & 0.13 & 0.09 & 0.49 & 0.35 & 0.15 & Kurang \\
\hline V15 & 0.29 & 0.23 & 0.35 & 0.18 & 0.51 & Baik \\
\hline V16 & 0.26 & 0.22 & 0.44 & 0.28 & 0.24 & Cukup \\
\hline V17 & 0.43 & 0.36 & 0.21 & 0.31 & 0.80 & Amat Baik \\
\hline V18 & 0.36 & 0.30 & 0.33 & 0.22 & 0.59 & Amat Baik \\
\hline V19 & 0.32 & 0.27 & 0.39 & 0.23 & 0.60 & Baik \\
\hline V20 & 0.49 & 0.42 & 0.34 & 0.27 & 0.71 & Amat Baik \\
\hline V21 & 0.73 & 0.61 & 0.33 & 0.24 & 0.50 & Amat Baik \\
\hline V22 & 0.55 & 0.46 & 0.21 & 0.22 & 0.88 & Amat Baik \\
\hline
\end{tabular}




\begin{tabular}{|c|c|c|c|c|c|c|}
\hline V23 & 0.22 & 0.18 & 0.31 & 0.24 & 0.58 & Cukup \\
\hline V24 & 0.27 & 0.23 & 0.47 & 0.27 & 0.23 & Baik \\
\hline V25 & 0.35 & 0.31 & 0.31 & 0.34 & 0.43 & Amat Baik \\
\hline V26 & 0.33 & 0.28 & 0.38 & 0.27 & 0.59 & Amat Baik \\
\hline V27 & 0.73 & 0.62 & 0.40 & 0.29 & 0.44 & Amat Baik \\
\hline V28 & 0.84 & 0.71 & 0.43 & 0.31 & 0.45 & Amat Baik \\
\hline V29 & 0.14 & 0.11 & 0.56 & 0.43 & 0.52 & Cukup \\
\hline V30 & 0.17 & 0.14 & 0.54 & 0.72 & 0.20 & Cukup \\
\hline V31 & 0.35 & 0.29 & 0.43 & 0.25 & 0.64 & Amat Baik \\
\hline V32 & 0.31 & 0.26 & 0.70 & 0.29 & 0.29 & Baik \\
\hline
\end{tabular}

Tabel 4.2. Hasil Normlisasi Data Uji

\begin{tabular}{|c|c|c|c|c|c|}
\hline Kecamatan & APK & APM & PAJ & Sis/Gur & AM \\
\hline Binuang & 0.36 & 0.32 & 0.37 & 0.41 & 0.64 \\
\hline Anreapi & 0.33 & 0.31 & 0.43 & 0.37 & 0.67 \\
\hline Tapango & 0.33 & 0.31 & 0.40 & 0.42 & 0.49 \\
\hline Mapilli & 0.37 & 0.33 & 0.41 & 0.43 & 0.61 \\
\hline Wonomulyo & 0.37 & 0.32 & 0.33 & 0.43 & 0.76 \\
\hline Campalagian & 0.33 & 0.31 & 0.44 & 0.43 & 0.61 \\
\hline Tutar & 0.28 & 0.27 & 0.34 & 0.47 & 0.50 \\
\hline Alu & 0.33 & 0.31 & 0.38 & 0.49 & 0.52 \\
\hline Luyo & 0.35 & 0.33 & 0.34 & 0.52 & 0.43 \\
\hline Balanipa & 0.32 & 0.31 & 0.33 & 0.52 & 0.68 \\
\hline Matakali & 0.37 & 0.34 & 0.40 & 0.42 & 0.57 \\
\hline Polewali & 0.39 & 0.35 & 0.31 & 0.38 & 0.88 \\
\hline Bulo & 0.25 & 0.24 & 0.48 & 0.46 & 0.49 \\
\hline Matangnga & 0.25 & 0.21 & 0.31 & 0.43 & 0.49 \\
\hline Limboro & 0.35 & 0.33 & 0.34 & 0.42 & 0.68 \\
\hline Tinambung & 0.35 & 0.32 & 0.56 & 0.51 & 0.35 \\
\hline
\end{tabular}

\subsubsection{Klasifikasi menggunakan SOM}

Pada tahapan kali ini yaitu penerapan metode SOM untuk klasifikasi, dalam proses klasifikasi maka langkah awal yang akan dilakukan adalah melakukan pelatihan terhadap data latih sebagai pembelajaran untuk data uji. Pada tahapan pertama akan dilakukan pelatihan dengan data latih yang memiliki 64 record selanjutnya melakukan pengujian terhadap data uji yang memiliki 16 record, pada proses komputasi ini dengan menggunakan 5000 iterasi. Hasil pengujian tersebut dapat pula dilihat pada tabel 4.3 berikut :

Tabel 4.3. Hasil Pengujian Data Uji

\begin{tabular}{|c|c|c|c|cc|c|}
\hline Kecamatan & APK & APM & PAJ & $\begin{array}{c}\text { R- } \\
\text { S/G }\end{array}$ & AM & Kelas \\
\hline Binuang & 107,01 & 95,26 & 3,67 & 16,56 & 128,46 & AB \\
\hline Anreapi & 99,16 & 92,39 & 4,28 & 14,68 & 133,20 & B \\
\hline Tapango & 99,85 & 93,92 & 3,95 & 16,83 & 97,35 & B \\
\hline Mapilli & 110,84 & 99,13 & 4,11 & 17,09 & 121,85 & AB \\
\hline Wonomulyo & 110,79 & 96,83 & 3,32 & 17,02 & 151,21 & AB \\
\hline Campalagian & 99,12 & 91,62 & 4,35 & 17,36 & 122,32 & AB \\
\hline Tutar & 85,40 & 81,09 & 3,43 & 18,74 & 99,21 & B \\
\hline Alu & 99,33 & 93,33 & 3,76 & 19,69 & 104,59 & AB \\
\hline Luyo & 103,82 & 98,75 & 3,35 & 20,99 & 85,39 & B \\
\hline Balanipa & 96,43 & 91,61 & 3,28 & 20,65 & 135,65 & AB \\
\hline Matakali & 112,16 & 101,24 & 3,95 & 16,78 & 113,28 & AB \\
\hline Polewali & 117,58 & 106,41 & 3,05 & 15,08 & 176,29 & AB \\
\hline Bulo & 75,48 & 72,65 & 4,81 & 18,27 & 98,77 & B \\
\hline Matangnga & 74,70 & 63,21 & 3,14 & 17,27 & 97,00 & B \\
\hline Limboro & 105,61 & 99,45 & 3,44 & 16,71 & 135,57 & AB \\
\hline Tinambung & 104,86 & 97,48 & 5,62 & 20,39 & 69,74 & B \\
\hline
\end{tabular}

Dari hasil pengujian diatas menunjukkan bahwa setiap kecamatan telah diklasifikasikan berdasarkan kelas masingmasing dan selanjutnya hasil pengujian tersebut di sajikan kedalam bentuk peta, Perbedaan warna yang disajikan pada peta menunjukkan kondisi pendidikan suatu wilayah. Hasil klasifikasi terlihat pada gambar 4.1.

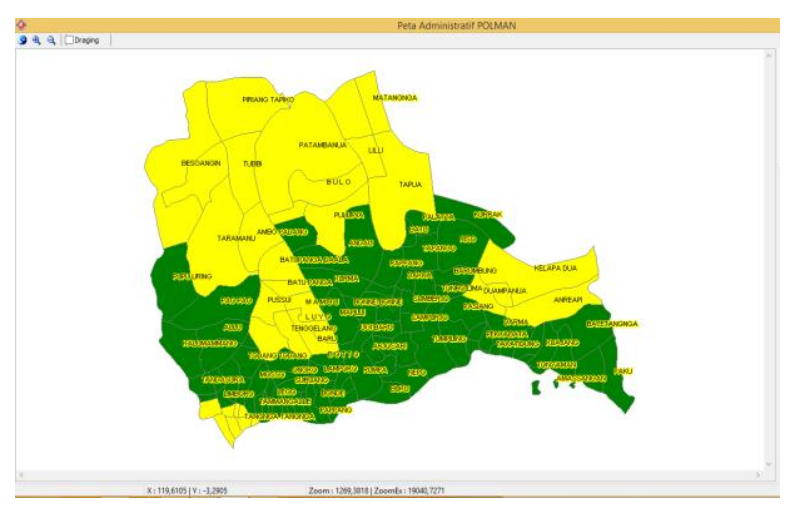

Gambar 4.1. Peta Pemetaan Pendidikan

Selanjutnya untuk melihat tingkat akurasi yang didapatkan dari hasil klasifikasi yang dilakukan maka data tersebut akan disesuaikan dengan data aktual yang berasal dari Dinas Pendidikan Kabupaten Polewali Mandar. Data aktual yang digunakan sebagai data uji terlihat pada tabel 4.3 berikut

Tabel 4.3. Data Aktual

\begin{tabular}{|c|c|c|c|c|c|c|}
\hline Kecamatan & APK & APM & PAJ & R-S/G & AM & Kelas \\
\hline Binuang & 107,01 & 95,26 & 3,67 & 16,56 & 128,46 & AB \\
\hline Anreapi & 99,16 & 92,39 & 4,28 & 14,68 & 133,20 & AB \\
\hline Tapango & 99,85 & 93,92 & 3,95 & 16,83 & 97,35 & B \\
\hline Mapilli & 110,84 & 99,13 & 4,11 & 17,09 & 121,85 & AB \\
\hline Wonomulyo & 110,79 & 96,83 & 3,32 & 17,02 & 151,21 & AB \\
\hline Campalagian & 99,12 & 91,62 & 4,35 & 17,36 & 122,32 & AB \\
\hline Tutar & 85,40 & 81,09 & 3,43 & 18,74 & 99,21 & B \\
\hline Alu & 99,33 & 93,33 & 3,76 & 19,69 & 104,59 & AB \\
\hline Luyo & 103,82 & 98,75 & 3,35 & 20,99 & 85,39 & AB \\
\hline Balanipa & 96,43 & 91,61 & 3,28 & 20,65 & 135,65 & AB \\
\hline Matakali & 112,16 & 101,24 & 3,95 & 16,78 & 113,28 & AB \\
\hline Polewali & 117,58 & 106,41 & 3,05 & 15,08 & 176,29 & AB \\
\hline Bulo & 75,48 & 72,65 & 4,81 & 18,27 & 98,77 & B \\
\hline Matangnga & 74,70 & 63,21 & 3,14 & 17,27 & 97,00 & B \\
\hline Limboro & 105,61 & 99,45 & 3,44 & 16,71 & 135,57 & AB \\
\hline Tinambung & 104,86 & 97,48 & 5,62 & 20,39 & 69,74 & B \\
\hline
\end{tabular}

Berdasarkan pada data aktual dari data uji hasil menunjukkan terdapat 3 kecamatan yang memiliki kelas berbeda. Seperti terlihat pada gambar 4.2 berikut

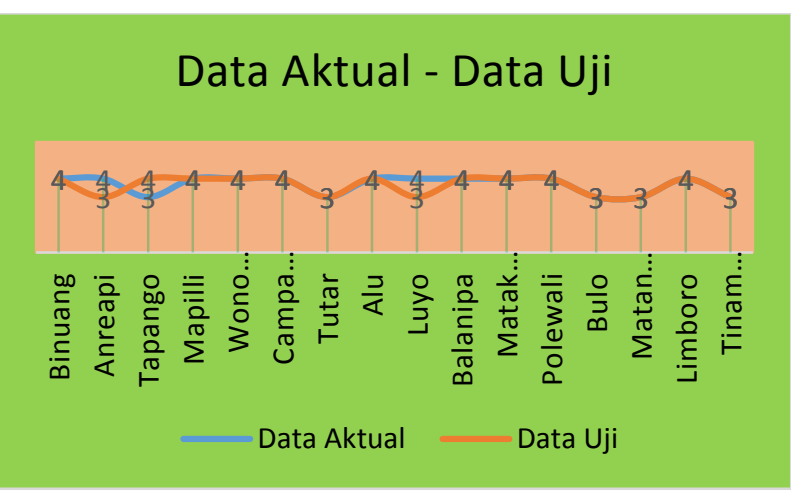

Gambar 4.2. Grafik Perbandingan data aktual dan data hasil pengujian 
Dari grafik diatas, Kelas AB ditunjukkan pada angka 4, kelas B ditunjukkan angka 3 dan dapat dilihat bahwa perbedaan kelas terjadi pada kecamatan anreapi dan kecamatan luyo dari kelas $\mathrm{AB}$ menjadi $\mathrm{B}$, kecamatan tapango dari kelas B menjadi AB. Dengan demikian terdapat 3 kecamatan yang tidak sesuai dengan kelasnya, adapun persentase akurasi kesesuaian berkisar $81.25 \%$ dan selanjutnya akan dilakukan pengujian untuk mengetahui faktor yang menyebabkan terjadinya perbedaan kelas.

Beberapa faktor yang akan diuji untuk mengetahui pengaruh dari terjadinya perubahan kelas dan akurasi pengklasifikasian, maka pada tahapan ini akan dilakukan pengujian terhadap jumlah data yang dijadikan sebagai data latih. Pada proses ini pengujian akan dilakukan sebanyak 3 kali, dengan mengubah jumlah data latih sebagai berikut

\section{Pengujian dengan 20 Data Latih}

Hasil dari pengujian dengan jumlah data latih sebanyak 20 data menunjukkan terdapat 5 kecamatan yang tidak sesuai dengan kelasnya seperti terlihat pada gambar 4.3 berikut.

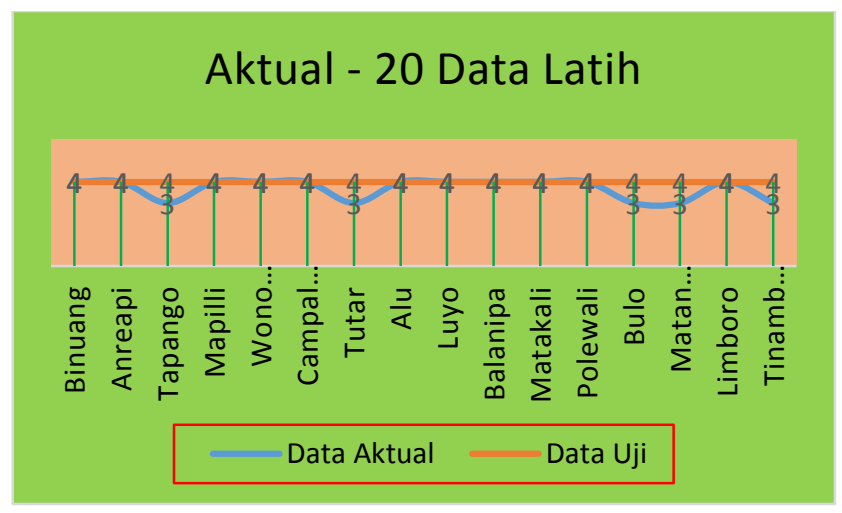

Gambar 4.3. Perbandingan Data Aktual dan 20 Data Latih

Dari grafik diatas dapat dilihat bahwa perbedaan kelas terjadi pada kecamatan tapango, kecamatan tutar, kecamatan bulo, kecamatan matangnga dan kecamatan tinambung perubahan kelas dari B menjadi AB. Dengan demikian hasil menujukkan bahwa tingkat akurasi dengan 20 data latih berkisar $68,75 \%$.

\section{Pengujian dengan 35 Data Latih}

Hasil dari pengujian dengan jumlah data latih sebanyak 35 data menunjukkan terdapat 5 kecamatan yang tidak sesuai dengan kelasnya seperti terlihat pada gambar 4.4 berikut.

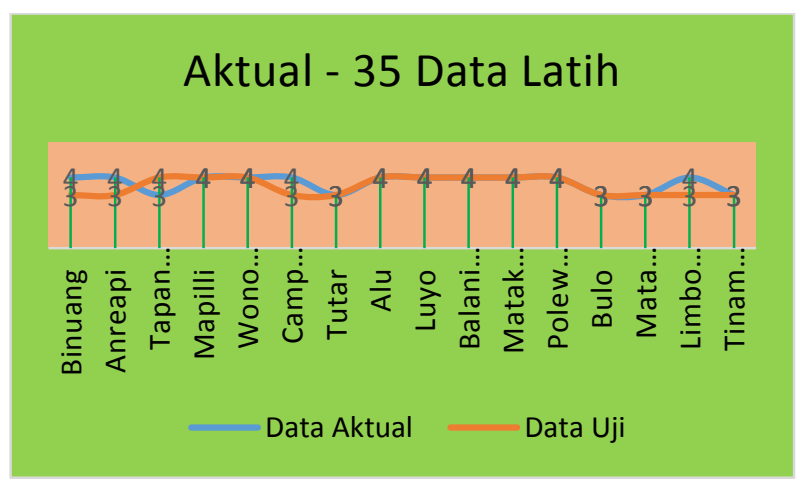

Gambar 4.4. Perbandingan Data Aktal dan 35 Data Latih
Dari grafik diatas dapat dilihat bahwa perbedaan kelas terjadi pada kecamatan binuang, kecamatan anreapi, kecamatan campalagian dan kecamatan limboro dari kelas AB menjadi B sedangkan kecamatan tapango dari kelas $\mathrm{B}$ menjadi AB. Dengan demikian hasil menujukkan bahwa tingkat akurasi dengan 35 data latih berkisar $68,75 \%$.

\section{Pengujian dengan 50 Data Latih}

Hasil dari pengujian dengan jumlah data latih sebanyak 50 data menunjukkan terdapat 4 kecamatan yang tidak sesuai dengan kelasnya seperti terlihat pada gambar 4.5 berikut.

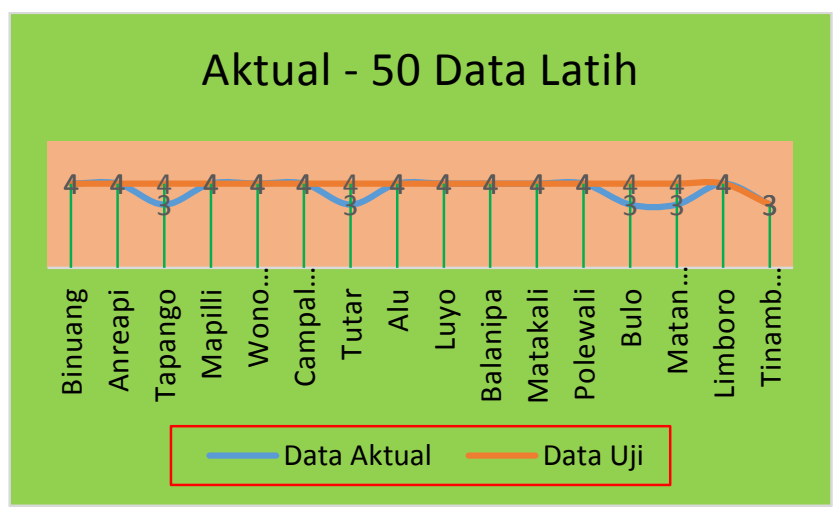

Gambar 4.5. Perbandingan Data Aktual dan 50 Data Latih

Dari grafik diatas dapat dilihat bahwa perbedaan kelas terjadi pada kecamatan tapango, kecamatan tutar, kecamatan bulo dan kecamatan matangnga dari kelas B menjadi AB. Dengan demikian hasil menujukkan bahwa tingkat akurasi dengan 50 data latih berkisar $75 \%$.

Berdasarkan hasil pengujian dengan menggunakan data latih yang berbeda yaitu 20 data latih, 35 data latih, dan 50 data latih diperoleh 2 hasil pengujian sebagai berikut :

\section{Tingkat Akurasi}

Dapat dilihat bahwa setiap data latih yang berbeda dapat mempengaruhi tingkat akurasi yang dihasilkan, untuk 20 data latih dan 35 data latih menghasilkan persentase akurasi kesesuaiannya $68,75 \%$, dan 50 data latih memiliki tingkat akurasi kesesuaiannya $75 \%$.

Hasil pengujian perbandingan antara data aktual, data uji dan data latih dari berbagai banyaknya jumlah data latih dapat dilihat pada gambar 4.6 sebagai berikut.

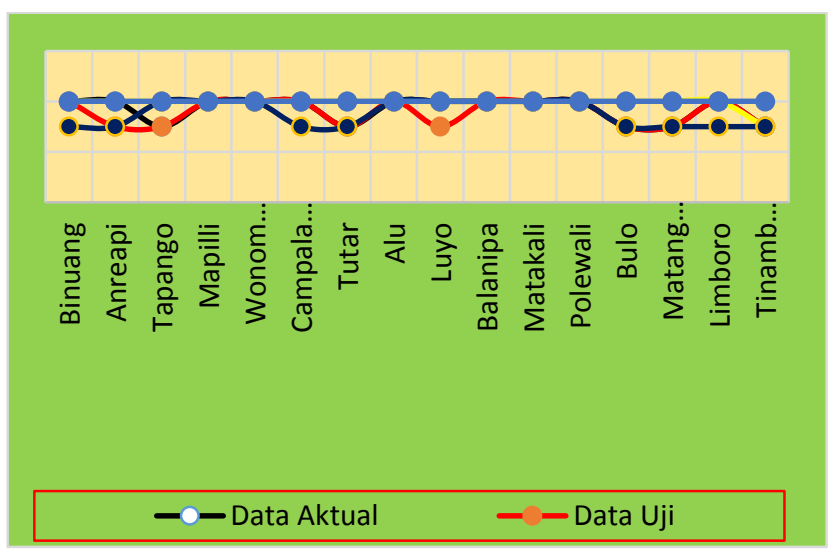

Gambar 4.6 Perbandingan Data Aktual dan Data Latih 
Dengan demikian pengujian ini menunjukkan bahwa semakin banyak data latih maka tingkat akurasinya akan semakin baik.

\section{Perubahan Kelas}

Dari hasil pengujian diatas menunjukkan terjadinya perubahan kelas pada setiap data latih yang berbeda, semakin sedikit data latih maka semakin banyak perubahan kelas yang terjadi. Pada pengujian dengan menggunakan 20 data latih perubahan kelas yang terjadi seperti pada gambar 4.7 sebagai berikut.

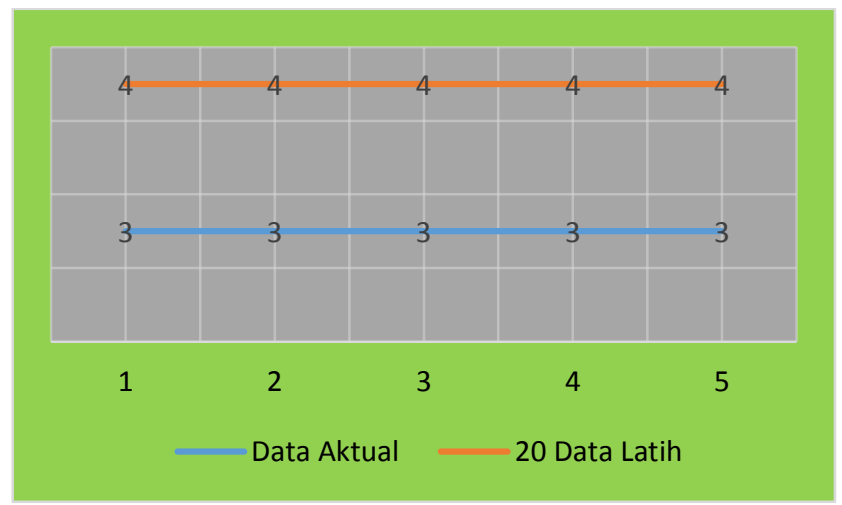

Gambar 4.7 Perubahan Kelas pada 20 Data Latih

Dari gambar 4. dapat dilihat bahwa perubahan kelas yang terjadi melangkah sebanyak 1 range yaitu B menjadi AB.

Selanjutnya Pada pengujian dengan menggunakan 35 data latih perubahan kelas yang terjadi seperti pada gambar 4.8 sebagai berikut.

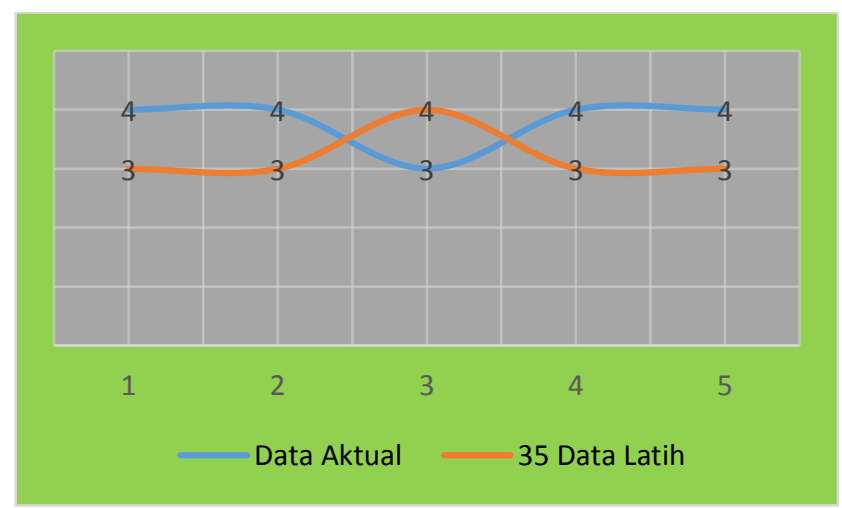

Gambar 4.8 Perubahan Kelas pada 35 Data Latih

Dari gambar 4.8 dapat dilihat bahwa terdapat 5 data yang perubahan kelasnya melangkah sebanyak 1 range, 4 data perubahan kelas dari $\mathrm{AB}$ menjadi $\mathrm{B}$ dan 1 data dari kelas B menjadi AB.

Selanjutnya Pada pengujian dengan menggunakan 50 data latih perubahan kelas yang terjadi seperti pada gambar 4.9 sebagai berikut.

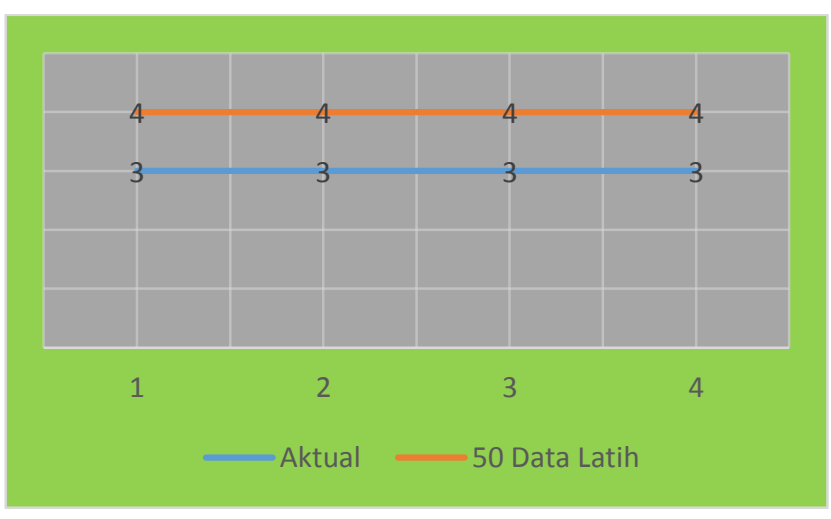

Gambar 4.9 Perubahan Kelas pada 50 Data Latih

Dari tabel diatas dapat dilihat bahwa perubahan kelas yang terjadi melangkah sebanyak 1 range yaitu dari kelas $B$ menjadi AB.

\section{Kesimpulan}

Berdasarkan hasil penelitian yang telah dilakukan, maka dapat diambil kesimpulan sebagai berikut :

1. Hasil penelitian menunjukkan bahwa metode SOM dalam melakukan Pemetaan untuk memetakan pendidikan pada suatu wilayah tingkat akurasi yang dihasilkan sebanyak 81,25\%.

2. Tingkat akurasi yang dihasilkan bergantung pada banyaknya jumlah data latih.

3. Baiknya tingkat akurasi yang dihasilkan ditentukan dari data yang digunakan sebagai data latih.

\section{Daftar Pustaka}

[1] Demuth, H., dan Beale, M., 2003, Neural Network Toolbox For Use with MATLAB, USA.

[2] Ehsani, A.H., dan Quiel, F., 2008, Geomorphometric feature analysis using morphometric parameterization and artificial neural networks. Geomorphology (99), $1-12$.

[3] Han, J., dan Kamber, M., 2001, Data Mining : Concepts and Techniques, USA.

[4] He, Z., Lin, S., Deng, Y., Li, X., dan Qian, Q., 2014, A rough membership neural network approach for fault classification in transmission lines, Electrical Power and Energy Systems, (61), 429 - 439.

[5] Jain, A.K., Mao, J., and Mohiuddin, K.M., 1996, Artificial Neural Networks: A Tutorial, IEEE Computer.

[6] Jimenez, F., Serradill, F., Roman, A., dan Naranjo, J.E., 2014, Bus line classification using neural networks, Transportations research part D, (30), 32 37.

[7] Kalteh, A.M., Hjorth, P., dan Berndtsson, R., 2008, Review of the Self organizing maps approach in water resources : Analysis, modeling and application, Environmental modeling and software (23), 835-845. 
[8] Koc, L., Mazzuchi, T.A., dan Sarkani, S., 2012, A network intrusion detection system based on a Hidden Naïve Bayes multiclass classifier, Expert system with applications (39), 13492-13500.

[9] Kohonen, T., 2001, Self-organizing maps, Springer Verlag.

[10] Kristanto, A., 2004, Jaringan Syaraf Tiruan, Gava Media, Yogyakarta.

[11] Larose, D.T., 2004, Discovering Knowledge in Data: An Introduction to Data Mining, John Wiley \& Sons,Inc.

[12] Lohr, S.C., Grigorescu, M., Hodgkinson, J.H., Cox, M.E., dan Fraser, S.J., 2010, Iron occurrence in soils and sediments of a coastal catchment A multivariate approach using self organising maps, Geoderma (156), 253-266.

[13] Pandit, Y.P., Badhe, Y.P., Sharma, B.K., Tambe, S.S., dan Kulkarni, B.D., 2011, Classification of Indian power coals using K-means clustering and Self Organizing Map neural network, Fuel (90), 339-347.

[14] Pisati, M., Whelan, C.T., Lucchini, M., dan Maitre, B., 2010, Mapping patterns of multiple deprivation using self-organising maps : An application to EU-SILC data for Ireland, Social Science Research (39), 405418.

[15] Permendagri nomor 54., 2010, Tata cara pengolahan data dan informasi perencanan pembangunan daerah, Kementrian dalam negeri, Indonesia.

[16] Prahasta, E., 2006, Membangun aplikasi web based GIS dengan map server, Informatika, Bandung.

[17] Prasetyo, E., 2012, Data mining, konsep dan aplikasi menggunakan matlab, Andi, Yogyakarta.

[18] Samarasinghe, S., 2006. Neural networks for applied sciences and engineering, Auerbach publication, Francis.

[19] Smith, M., 1996, Neural Networks for Statistical Modeling, International Thompson Computer Press, London.
[20] Sugiyono., 2009. Metode Penelitian Kuantitatif Kualitatif dan $R \& D$, Alfabeta Bandung.

[21] Turban, B., dan Bener, A., 2009, Analysis of Naive Bayes' assumptions on software fault data : An empirical study, Data \& Knowledge Engineering (68), 278-290.

[22] Undang-undang nomor 20., 2003, Standar sistem pelayanan pendidikan, Indonesia.

[23] [22] Wang, D., dan Gao, M., 2013, Educational equality or social mobility : The value conflict between preservice teachers and the Free Teacher Education Program in China, Teaching and Teacher Education (32), 66-74.

[24] Wang, G.A., Atabakhsh, H., dan Chen, H., 2011. A hierarchical Naïve Bayes model for approximate identity matching, Decision support system (51), 413423.

[25] Widayati, N., Hariadi, M dan Mardi, S., 2011. Pemetaan prioritas perencanaan pembangunan berbasis penggalian data multidimensi menggunakan websom, Magister tesis, Institut tehnologi sepuluh nopember, Surabaya.

[26] Zhang, C., 2009, An empirical study on the relationship between educational equity and the quality of economic growth in China : 1978-2004, Economic Journal (54), 125-134.

[27] Zhang, H., Liu, J., Ma, D., dan Wang, Z., 2011, Data core based fuzzy min - max neural networks for pattern classification, Neural Networks (22), 2339 2352.

[28] Zhang, Y., Yin, Y., Guo, D., Yu, X., dan Xiao, L., 2014, Cross validation based weights and structure determination of Chebyshev-polynomial neural networks for pattern classification, Pattern recognition (47), 3414-3428. 